\title{
Support Effect on Carbon Nanotube Growth by Methane Chemical Vapor Deposition on Cobalt Catalysts
}

\author{
Hugo A. Oliveira, ${ }^{a}$ Dante F. Franceschini ${ }^{b}$ and Fabio B. Passos $*, a$ \\ ${ }^{a}$ Departamento de Engenharia Química e Petróleo, Universidade Federal Fluminense, \\ Rua Passos da Pátria, 156, 24210-040 Niterói-RJ, Brazil \\ ${ }^{b}$ Instituto de Física, Universidade Federal Fluminense, \\ Av. Milton Tavares de Souza s/n, 24210-341 Niterói-RJ, Brazil
}

\begin{abstract}
A influência do suporte na produção de nanotubos de carbono por deposição química a vapor (CVD) de metano sobre catalisadores de cobalto foi investigada. As técnicas de fisissorção de $\mathrm{N}_{2}$, difratometria de raios X (XRD), redução à temperatura programada (TPR) e quimissorções de $\mathrm{H}_{2}$ e $\mathrm{CO}$ foram usadas na caracterização dos catalisadores de cobalto suportados em diferentes óxidos $\left(\mathrm{Al}_{2} \mathrm{O}_{3}, \mathrm{SiO}_{2}, \mathrm{Nb}_{2} \mathrm{O}_{5}\right.$ e TiO$\left.{ }_{2}\right)$. As técnicas de espectroscopia Raman, oxidação a temperatura programada (TPO) e microscopia eletrônica de varredura (SEM) foram utilizadas na caracterização e quantificação de espécies de carbono produzidas. No crescimento dos nanotubos, o catalisador produziu três espécies principais de carbono: carbono amorfo, nanotubos de carbono de parede única (SWNT) e nanotubos de carbono de parede múltiplas (MWNT). Técnicas de caracterização mostraram que a seletividade catalítica a cada tipo de nanotubo depende da distribuição do tamanho de partículas de cobalto, a qual depende das propriedades texturais do suporte. O catalisador $\mathrm{Co} / \mathrm{TiO}_{2}$ apresentou alta seletividade para a produção de nanotubos de parede única. Esta alta seletividade se deve a uma distribuição estreita do tamanho de partículas de cobalto sobre $\mathrm{TiO}_{2}$.
\end{abstract}

The influence of the support on carbon nanotube production by methane chemical vapor deposition (CVD) on cobalt catalysts was investigated. $\mathrm{N}_{2}$ physisorption, X-ray diffractometry (XRD), temperature programmed reduction (TPR) and $\mathrm{H}_{2}$ and $\mathrm{CO}$ chemisorption techniques were used to characterize the structure of cobalt catalysts supported on different metal oxides $\left(\mathrm{Al}_{2} \mathrm{O}_{3}\right.$, $\mathrm{SiO}_{2}, \mathrm{Nb}_{2} \mathrm{O}_{5}$ and $\mathrm{TiO}_{2}$ ). Raman spectroscopy, temperature programmed oxidation (TPO) and scanning electron microscopy (SEM) were used for the characterization and quantification of produced carbon species. On carbon nanotube growth, the catalyst produced three main carbon species: amorphous carbon, single walled carbon nanotubes (SWNT) and multi walled carbon nanotubes (MWNT). The characterization techniques showed that the catalyst selectivity to each kind of nanotube depended on the cobalt particle size distribution, which was influenced by the textural properties of the support. $\mathrm{Co} / \mathrm{TiO}_{2}$ showed the highest selectivity towards single wall nanotube formation. This high selectivity results from the narrow size distribution of cobalt particles on $\mathrm{TiO}_{2}$.

Keywords: carbon nanotubes, cobalt, catalyst support, chemical vapor deposition, methane

\section{Introduction}

In the last fifteen years, the research on carbon nanotube (CNT) production by chemical vapor deposition (CVD) has attracted great attention due to its easy setup and scaleup for mass production. ${ }^{1}$ A large number of researchers have studied different operational conditions and catalyst formulations for CNT production. ${ }^{1-7}$ However, these

*e-mail: fbpassos@vm.uff.br operational conditions and catalysts formulations are not well established. Carbon nanotubes synthesis groups ${ }^{8-12}$ are still developing new catalyst formulations for improving CNT production.

On catalytic carbon nanotube production, it is well-known that the support plays an important role in the dispersion and catalytic activity of the metal present on it. ${ }^{13}$ The metal properties on a supported catalyst depend on the metal-support interaction which in turn depends on the nature of the support. In this way, a detailed characterization 
of the catalyst, support and metal particle is needed to understand its effects on CNT production.

The present work reports a study on the support influence $\left(\mathrm{Al}_{2} \mathrm{O}_{3}, \mathrm{SiO}_{2}, \mathrm{TiO}_{2}\right.$ and $\left.\mathrm{Nb}_{2} \mathrm{O}_{5}\right)$ on CNT production by methane CVD on 4 wt.\% cobalt catalysts. The studied catalysts were characterized by X-ray diffractometry (XRD), $\mathrm{N}_{2}$ physisorption, temperature programmed reduction (TPR) and $\mathrm{H}_{2}$ and $\mathrm{CO}$ chemisorptions. For the carbon species obtained by methane CVD, it was used the following characterization techniques: Raman spectroscopy (which is an effective technique for characterizing the structure of single walled carbon nanotubes (SWNT) $)^{3,14}$ temperature programmed oxidation (TPO) (which can quantify the amount of amorphous carbon, SWNT and multi walled carbon nanotubes (MWNT) present on a sample) $)^{15}$ and scanning electron microscopy (SEM) (which has been used to investigate the CNT morphologies). In addition, it was studied the methane decomposition on these catalysts, first step on the CNT mechanism growth. The obtained results allowed identifying how the metal and support influenced the carbon nanotube formation.

\section{Experimental}

\section{Catalyst preparation}

Four different supports were studied in this work: $\mathrm{Al}_{2} \mathrm{O}_{3}$ (Catapal-A Bohemite, Hamburg, Germany) $\mathrm{SiO}_{2}$ (Davicat SP 550-10022, Worms, Germany), $\mathrm{TiO}_{2}$ (Degussa P25, Hanau-Wolfgang, Germany) and $\mathrm{Nb}_{2} \mathrm{O}_{5}$ (niobic acid, HY 340 CBMM, Araxá, Brazil). The supports were dried in air at $393 \mathrm{~K}$ for $16 \mathrm{~h}$ and then heated in air at a heating rate of $10 \mathrm{~K} \mathrm{~min}^{-1}$ up to $773 \mathrm{~K}$ and kept at the final temperature for $2 \mathrm{~h}$.

A set of $4 \mathrm{wt} . \%$ Co catalysts was prepared by incipient wetness impregnation using a solution of $\mathrm{Co}\left(\mathrm{NO}_{3}\right)_{2} \cdot 6 \mathrm{H}_{2} \mathrm{O}$ (Merck, Darmstadt, Germany). After impregnation, the catalysts were dried in air at $393 \mathrm{~K}$ for $16 \mathrm{~h}$ and then calcined in air for $2 \mathrm{~h}$ at $773 \mathrm{~K}$.

\section{Catalyst characterization}

X-ray diffractometry (XRD) experiments of the calcined samples were performed in a Rigaku Miniflex diffractrometer using monochromatic $\mathrm{Cu}-\mathrm{K}_{\alpha}(1.540 \AA)$ radiation with a scan rate of 0.05 degree $\mathrm{min}^{-1}$.

Measurements of BET specific surface area, pore volume and pore diameter distribution were performed in an ASAP 2010 Micromeritics apparatus by $\mathrm{N}_{2}$ adsorption. The samples were evacuated at $493 \mathrm{~K}$ during 4 hours before analysis. Pore volume and pore diameter distribution were calculated from the $\mathrm{N}_{2}$ desorption curve using the BarrettJoyner-Halenda (BJH) method.

Temperature programmed reduction (TPR) experiments were performed in a U-shaped tubular quartz reactor coupled to a quadrupole mass spectrometer (Omnistar, Balzers). The catalysts $(0.5 \mathrm{~g})$ were dried in $\mathrm{He}$ for $30 \mathrm{~min}$ at $473 \mathrm{~K}$ before TPR analysis. After cooling to room temperature, a mixture of $5 \% \mathrm{H}_{2} / \mathrm{Ar}$ flowed through the catalyst $(30 \mathrm{sccm})$ and the temperature was raised at a heating rate of $10 \mathrm{~K} \mathrm{~min}^{-1}$ up to $1273 \mathrm{~K}$.

$\mathrm{H}_{2}$ and $\mathrm{CO}$ chemisorptions were performed using a volumetric method in a Micromeritcs ASAP 2010C device. The pretreatment of the catalysts consisted of drying at $493 \mathrm{~K}$ for $30 \mathrm{~min}$ under a $30 \mathrm{sccm}$ of He flow before the reduction. After cooling to room temperature, the catalysts $(0.5 \mathrm{~g})$ were reduced under $30 \mathrm{sccm}$ of $\mathrm{H}_{2}$, and the temperature was raised at a heating rate of $10 \mathrm{~K} \mathrm{~min}^{-1}$ up to $973 \mathrm{~K}$, the same reduction temperature used in the catalytic runs. The reduced catalysts were outgassed under vacuum at $973 \mathrm{~K}$ before cooling to $423 \mathrm{~K}$, where the $\mathrm{H}_{2}$ chemisorption measurements (activated chemisorption) ${ }^{16}$ were performed. Then, the catalysts were evacuated at $773 \mathrm{~K}$, and finally the $\mathrm{CO}$ chemisorption measurements were performed at $308 \mathrm{~K}$. Both total and reversible isotherms were measured at the pressure range of 10-300 mmHg. The amount of $\mathrm{H}_{2}$ and $\mathrm{CO}$ adsorbed in each measurement was determined by extrapolating the linear part of the isotherm to zero pressure. It is assumed that the adsorption stoichiometries for $\mathrm{H}_{2}$ and $\mathrm{CO}$ are $\mathrm{H}: \mathrm{Co}=1$ and $\mathrm{CO}: \mathrm{Co}=1$, respectively. The Co particle size $\left(\mathrm{d}_{\mathrm{p}}\right)$ was calculated supposing the Co particles are spherical. For $\mathrm{H}_{2}$ chemisorption, these calculations were performed assuming total chemisorption as recommended by Bartholomew. ${ }^{17}$

\section{Methane conversion}

Catalytic activity was investigated $\mathrm{CH}_{4}$ pulsing over the catalysts $(0.1 \mathrm{~g})$ packed in a quartz reactor attached to a mass spectrometer (Omnistar, Balzers). After the reduction from room temperature to $973 \mathrm{~K}$ at a rate of $10 \mathrm{~K} \mathrm{~min}^{-1}$ under $\mathrm{H}_{2}$ flow $(30 \mathrm{sccm})$, the catalysts were purged with He flow $(30 \mathrm{sccm})$ for $15 \mathrm{~min}$ before starting the pulses. During $\mathrm{CH}_{4}$ pulses, there was a constant He flow through the reactor, and the $\mathrm{CH}_{4}$ was flushed with carrier gas. The time interval between the first and the second pulse was $8 \mathrm{~min}(4 \mathrm{~min}$ for loading the pulse and $4 \mathrm{~min}$ for the injection of the pulse) and, thereafter, 6 min between pulses. Each pulse enclosed $0.5 \mathrm{ml}$ of $\mathrm{CH}_{4}$ at $393 \mathrm{~K}$. The methane conversion $\left(\mathrm{X}_{\mathrm{CH}_{4}}\right)$ was defined as follows: 
$\mathrm{X}_{\mathrm{CH}_{4}}=\frac{\mathrm{A}_{\text {Blank }}-\mathrm{A}_{\text {Reactor }}}{\mathrm{A}_{\text {Blank }}}$

where $A_{B l a n k}$ is the area monitored by a mass spectrometer corresponding to the total amount of methane injected in each pulse (without reaction) and $\mathrm{A}_{\text {Reactor }}$ is the area monitored by a mass spectrometer corresponding to methane left after the reaction step.

\section{CNT production}

For the CNT production by the CVD method, $1.0 \mathrm{~g}$ of catalyst was put into a quartz boat and then placed in a horizontal tubular quartz reactor. The catalyst was heated in $200 \mathrm{sccm}$ under $\mathrm{H}_{2}$ flow from room temperature to reduction temperature $(973 \mathrm{~K})$ at a heating rate of $10 \mathrm{~K} \mathrm{~min}^{-1}$. Then, $\mathrm{H}_{2}$ flow was switched to $\mathrm{CH}_{4}$ flow $(200 \mathrm{sccm})$ for $30 \mathrm{~min}$. Finally, the sample was cooled to room temperature under Ar flow (200 sccm).

\section{CNT characterization}

Raman spectroscopy was used for the characterization of unpurified carbon deposits. Raman spectra were taken in a Jobin-Yvon Raman spectrometer with a $532 \mathrm{~nm}$ laser excitation.

Temperature programmed oxidation (TPO) experiments were performed in the same apparatus described for TPR experiments. The samples $(0.2 \mathrm{~g})$ were dried in $\mathrm{He}$ for 30 min at $473 \mathrm{~K}$ before TPO analysis. After sample cooling to room temperature, a $5 \% \mathrm{O}_{2} / \mathrm{He}$ mixture flowed through the catalyst at $30 \mathrm{sccm}$ as temperature was raised at a heating rate of $10 \mathrm{~K} \mathrm{~min}^{-1}$ up to $1273 \mathrm{~K}$.

CNT morphology was analyzed by scanning electron microscope (SEM) images. SEM images were performed on a Jeol Mod. JSM-5800 LV with electron beam energy in the $10-30 \mathrm{kV}$ range.

\section{Results and Discussion}

\section{Characterization of the calcined catalysts}

\section{$\mathrm{X}$-ray diffractometry (XRD)}

Figure 1 shows the XRD patterns taken from the $\mathrm{Co}_{3} \mathrm{O}_{4}$ reference sample and from the calcined catalysts. For the $\mathrm{Co} / \mathrm{SiO}_{2}$ catalyst, there is a relatively broad peak at $2 \theta=22^{\circ}$ characteristic of amorphous silica and another two peaks at $2 \theta=37^{\circ}$ and $2 \theta=65^{\circ}$, which are related to the presence of crystalline $\mathrm{Co}_{3} \mathrm{O}_{4} \cdot{ }^{3}$ For this catalyst, only $\mathrm{Co}_{3} \mathrm{O}_{4}$ XRD peaks were observed, confirming that $\mathrm{Co}_{3} \mathrm{O}_{4}$ was the main crystalline phase. The average $\mathrm{Co}_{3} \mathrm{O}_{4}$ particle size was calculated to be $18.5 \mathrm{~nm}$ from the two most intense $\mathrm{Co}_{3} \mathrm{O}_{4}$ peaks $\left(2 \theta=37^{\circ}\right.$ and $\left.2 \theta=59^{\circ}\right)$ using the Scherrer equation and considering the sample broadening larger than the instrument broadening. ${ }^{18}$

The $\mathrm{Co} / \mathrm{Nb}_{2} \mathrm{O}_{5}$ catalyst exhibited XRD peaks at $2 \theta=23^{\circ}, 28^{\circ}$ and $37^{\circ}$, which are indicatives of the T- and TT- $\mathrm{Nb}_{2} \mathrm{O}_{5}$ phases. ${ }^{19}$ The $\mathrm{Nb}_{2} \mathrm{O}_{5}$ XRD pattern has a number of lines that superimpose the $\mathrm{Co}_{3} \mathrm{O}_{4}$ XRD lines making $\mathrm{Co}_{3} \mathrm{O}_{4}$ detection impractical.

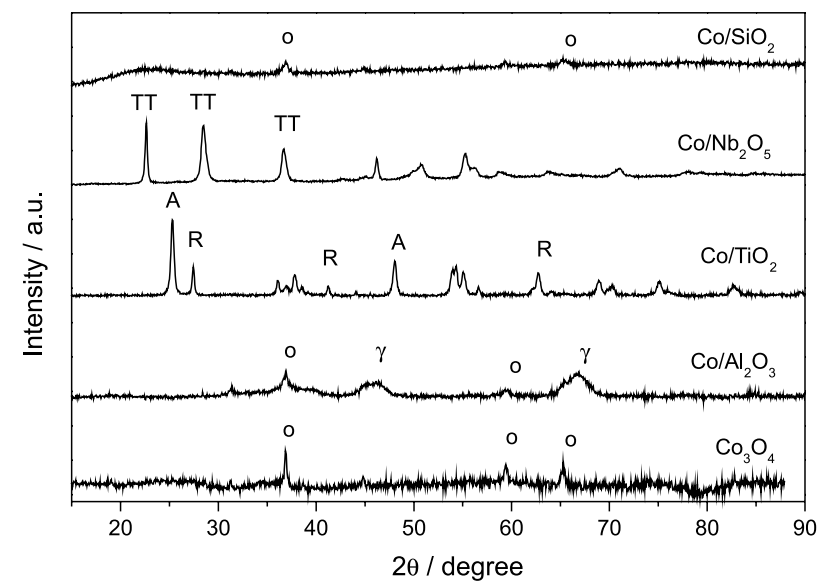

Figure 1. X-ray diffraction pattern for $\mathrm{Co} / \mathrm{SiO}_{2}, \mathrm{Co} / \mathrm{Nb}_{2} \mathrm{O}_{5}, \mathrm{Co} / \mathrm{TiO}_{2}$, $\mathrm{Co} / \mathrm{Al}_{2} \mathrm{O}_{3}$ and $\mathrm{Co}_{3} \mathrm{O}_{4}$. Phases: (A) anatase, (R) rutile, (O) $\mathrm{Co}_{3} \mathrm{O}_{4}$, $(\gamma) \gamma-\mathrm{Al}_{2} \mathrm{O}_{5}$, (T) $\mathrm{T}-\mathrm{Nb}_{2} \mathrm{O}_{5}$ and $(\mathrm{TT}) \mathrm{TT}-\mathrm{Nb}_{2} \mathrm{O}_{5}$.

For a $773 \mathrm{~K}$ calcination temperature, a phase composition of $30 \%$ anatase and $70 \%$ rutile phase $\mathrm{TiO}_{2}$ is expected. ${ }^{20}$ However, the anatase XRD peaks $\left(2 \theta=25^{\circ}\right.$ and $2 \theta=48^{\circ}$ ) were much stronger than the rutile peaks. So, the $\mathrm{TiO}_{2}$ supports may be mainly in the anatase phase. No $\mathrm{Co}_{3} \mathrm{O}_{4}$ XRD peak was observed for this calcined catalyst indicating that the cobalt particles were highly dispersed on this support.

The $\mathrm{Co} / \mathrm{Al}_{2} \mathrm{O}_{3}$ catalysts exhibited XRD peaks at $2 \theta=46^{\circ}$ and $2 \theta=68^{\circ}$, which are assigned to the $\gamma$-phase of the alumina, ${ }^{19}$ and peaks at $2 \theta=37^{\circ}$ and $2 \theta=59^{\circ}$, which are related to the presence of crystalline $\mathrm{Co}_{3} \mathrm{O}_{4}$. Using the Scherrer equation, ${ }^{18} \mathrm{a} \mathrm{Co}_{3} \mathrm{O}_{4}$ particle size equal to $16.8 \mathrm{~nm}$ was determined.

\section{$\mathrm{N}_{2}$ physisorption}

Many authors have observed a correlation between the size of the catalyst particles and the CNT diameter. ${ }^{22-27} \mathrm{An}$ increase in specific surface area of the support can lead to a decrease in Co particle size.$^{28}$ Among the studied supports, $\mathrm{SiO}_{2}$ showed the highest specific surface area followed by $\mathrm{Al}_{2} \mathrm{O}_{3}, \mathrm{TiO}_{2}$ and $\mathrm{Nb}_{2} \mathrm{O}_{5}$ (Table 1). Thus, $\mathrm{Co} / \mathrm{SiO}_{2}$ catalyst was expected to show the lower average Co particle size. However, the XRD analyses showed that $\mathrm{Co}_{3} \mathrm{O}_{4}$ particles supported on alumina are smaller than those supported on silica. 
Table 1. Specific surface area, average pore diameter, pore volume and $\mathrm{Co}_{3} \mathrm{O}_{4}$ particle size of supports and catalysts

\begin{tabular}{lcccc}
\hline Sample & $\mathrm{S}_{\mathrm{BET}} /\left(\mathrm{m}^{2} \mathrm{~g}^{-1}\right)$ & Average pore diameter $/ \mathrm{nm}$ & Pore volume $/\left(\mathrm{cm}^{3} \mathrm{~g}^{-1}\right)$ & $\mathrm{Co}_{3} \mathrm{O}_{4}$ diameter $/ \mathrm{nm}$ \\
\hline $\mathrm{SiO}$ & 435 & 14.8 & 1.6 & - \\
$\mathrm{Co} / \mathrm{SiO}_{2}$ & 423 & 14.5 & 1.5 & 18.5 \\
$\mathrm{Al}_{2} \mathrm{O}_{3}$ & 282 & 9.0 & 0.6 & - \\
$\mathrm{Co}_{\mathrm{Al}} \mathrm{O}_{3}$ & 248 & 9.6 & 0.6 & 16.8 \\
$\mathrm{TiO}_{2}$ & 63 & 44.9 & 0.7 & - \\
$\mathrm{Co}_{2} / \mathrm{TiO}_{2}$ & 63 & 36.7 & 0.6 & - \\
$\mathrm{Nb}_{2} \mathrm{O}_{5}$ & 31 & 17.6 & 0.1 & - \\
$\mathrm{Co}_{2} / \mathrm{Nb}_{2} \mathrm{O}_{5}$ & 27 & 20.3 & 0.1 & - \\
$\mathrm{S}$ & & & & - \\
\hline
\end{tabular}

$\mathrm{S}_{\mathrm{BET}}$ : specific surface area.

According to Jeong et al. ${ }^{29}$ and Duesberg et al. ${ }^{30}$ when the Co particles were mounted on a porous support, the diameter of the cobalt oxide can be limited by the pore size and, as a consequence, the resulting CNT and the porous support must have about the same diameter. ${ }^{29,30}$ Figure 2 shows the pore size distribution for the supports. The $\mathrm{Al}_{2} \mathrm{O}_{3}$ and $\mathrm{SiO}_{2}$ supports presented narrow pore size distributions, while $\mathrm{Nb}_{2} \mathrm{O}_{5}$ and $\mathrm{TiO}_{2}$ showed broader ones, with a high fraction of large pores. $\mathrm{Al}_{2} \mathrm{O}_{3}$ displayed the
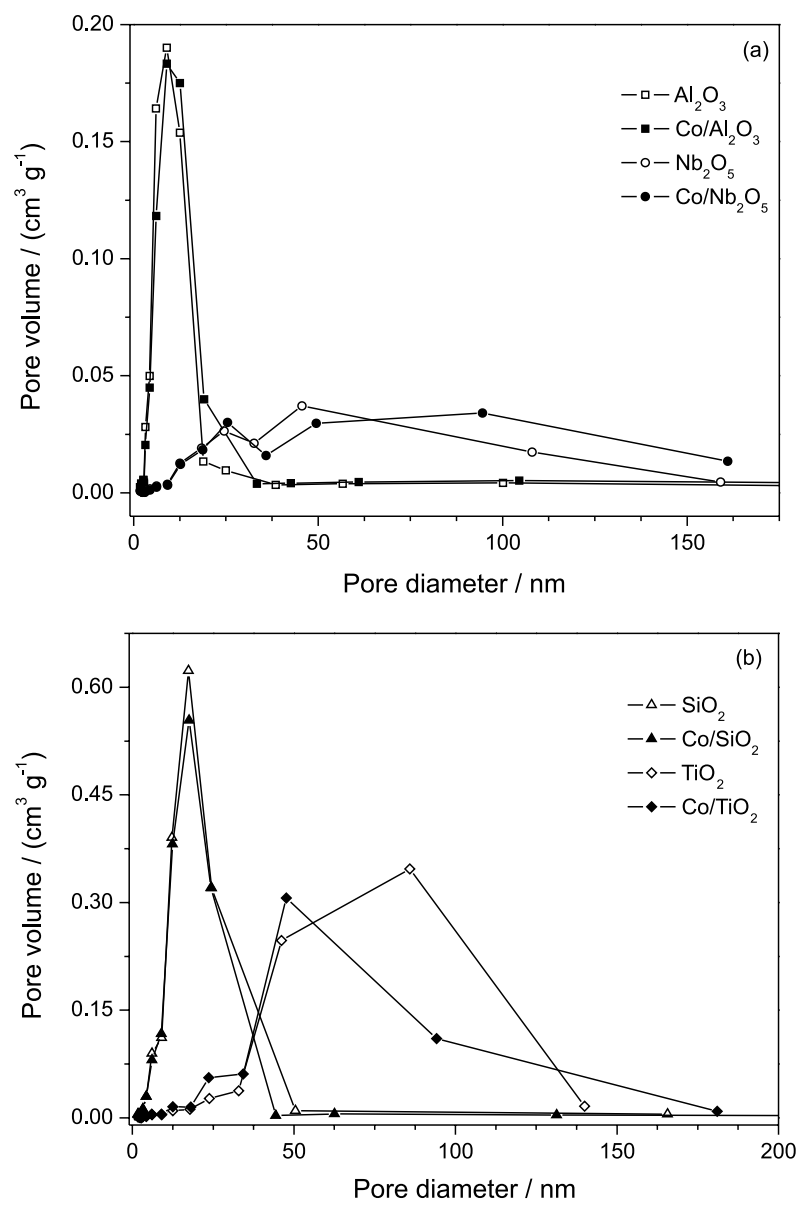

Figure 2. $\mathrm{BJH}$ pore size distribution from the nitrogen desorption curve for (a) $\mathrm{Al}_{2} \mathrm{O}_{3}, \mathrm{Co} / \mathrm{Al}_{2} \mathrm{O}_{3}, \mathrm{Nb}_{2} \mathrm{O}_{5}$ and $\mathrm{Co} / \mathrm{Nb}_{2} \mathrm{O}_{5}$, and (b) $\mathrm{SiO}_{2}, \mathrm{Co} / \mathrm{SiO}_{2}$, $\mathrm{TiO}_{2}$ and $\mathrm{Co} / \mathrm{TiO}_{2}$. narrowest pore size distribution. This textural property explains the fact that cobalt particles supported on alumina are smaller than ones supported on silica.

The Co impregnation had no major effect on the pore size distributions of the supports, except for $\mathrm{TiO}_{2}$ (Figure 2). The average pore diameter and pore volume of $\mathrm{TiO}_{2}$ reduced by 18 and 19\%, respectively (Table 1 ).

In addition to the specific surface area and the pore size distributions, the pore volume of the support may have an effect on the CNT production due to its function as a carbon trap. ${ }^{31}$ The specific surface area and the pore volume of the catalysts increased in the same order $\left(\mathrm{Nb}_{2} \mathrm{O}_{5}<\mathrm{TiO}_{2}<\right.$ $\mathrm{Al}_{2} \mathrm{O}_{3}<\mathrm{SiO}_{2}$ ).

\section{Temperature programmed reduction (TPR)}

The TPR profiles of the catalysts are displayed in Figure 3a. The TPR profile of $\mathrm{Co} / \mathrm{Nb}_{2} \mathrm{O}_{5}$ catalyst presented two peaks. The first peak (at $678 \mathrm{~K}$ ) may be attributed to the reduction of $\mathrm{Co}_{3} \mathrm{O}_{4}$ to $\mathrm{CoO}$. The second peak (at $771 \mathrm{~K}$ ) is attributed to a parallel reduction of $\mathrm{CoO}$ formed from $\mathrm{Co}_{3} \mathrm{O}_{4}$ reduction (first peak) and of $\mathrm{CoO}$ in strong interaction with the support. ${ }^{32}$

The TPR profile of $\mathrm{Co} / \mathrm{TiO}_{2}$ is analogous to the $\mathrm{Co} / \mathrm{Nb}_{2} \mathrm{O}_{5}$, suggesting similar reduction steps as found by other authors. ${ }^{33}$

For $\mathrm{Co} / \mathrm{Al}_{2} \mathrm{O}_{3}$, the reduction profile shows a small shoulder at $631 \mathrm{~K}$ and two reduction peaks at 779 and $1019 \mathrm{~K}$. The small shoulder and the first reduction peak are attributed to the reduction in two steps of $\mathrm{Co}_{3} \mathrm{O}_{4}$ particles, $\mathrm{Co}_{3} \mathrm{O}_{4} \rightarrow \mathrm{CoO} \rightarrow \mathrm{Co}$ (Figure 3b). The third peak is associated with the reduction of $\mathrm{CoO}$ linked to the support. The reduction of this species was shifted to higher temperatures. This shift can be explained due the stronger interaction between the support and $\mathrm{CoO}$ species. Storsæter et al. ${ }^{34}$ showed that strong interactions between the support and the smallest cobalt particles exist and increase with a higher dispersion of cobalt on the surface of the supports.

The reduction profile of $\mathrm{Co} / \mathrm{SiO}_{2}$ shows two reduction peaks and a shoulder around $958 \mathrm{~K}$. The reduction peaks 

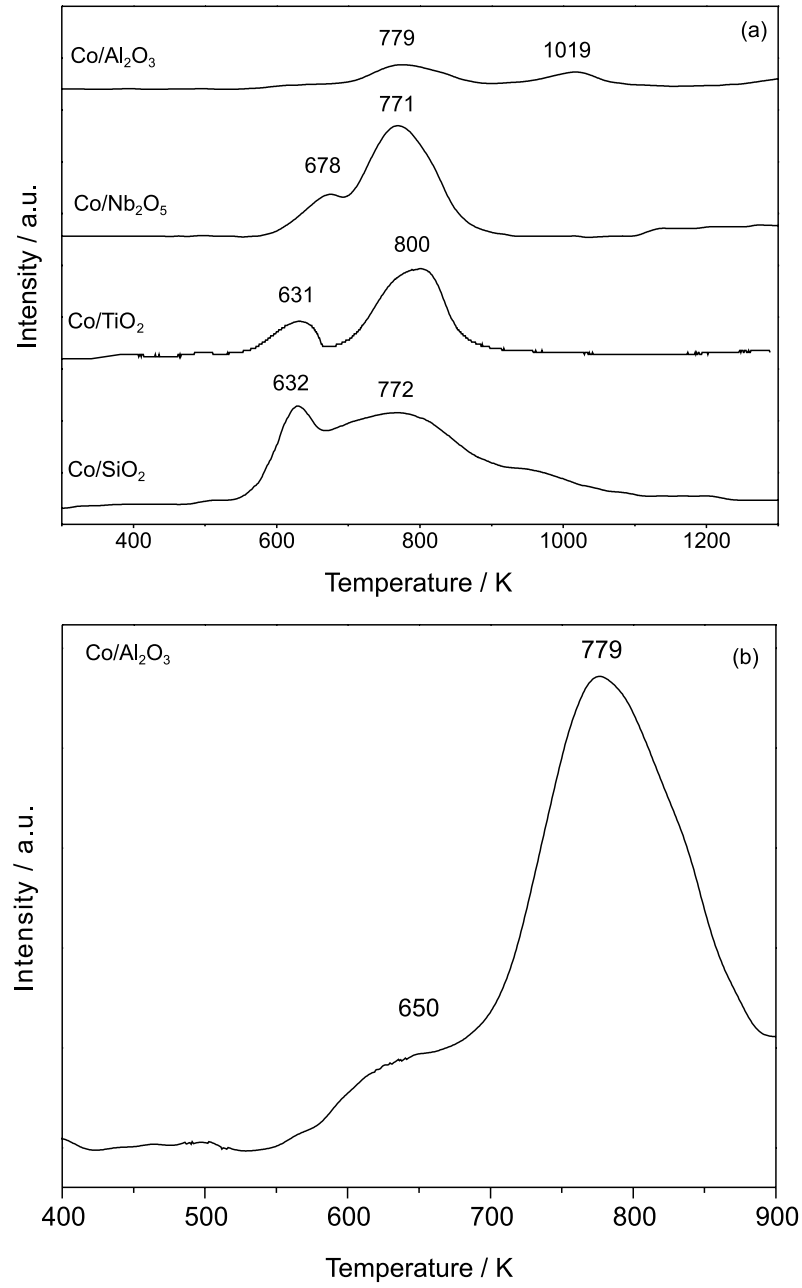

Figure 3. (a) TPR profiles of catalysts $\left(\mathrm{Co} / \mathrm{Al}_{2} \mathrm{O}_{3}, \mathrm{Co} / \mathrm{Nb}_{2} \mathrm{O}_{5}, \mathrm{Co} / \mathrm{TiO}_{2}\right.$ and $\mathrm{Co} / \mathrm{SiO}_{2}$ ) and (b) $\mathrm{Co} / \mathrm{Al}_{2} \mathrm{O}_{3}$ TPR profile. The reduction was conducted under $5 \% \mathrm{H}_{2} / \mathrm{Ar}$, using a heating rate of $10 \mathrm{~K} \mathrm{~min}^{-1}$.

at 632 and $772 \mathrm{~K}$ appear at similar temperatures to the reduction temperatures of the unsupported $\mathrm{Co}_{3} \mathrm{O}_{4} \cdot{ }^{32}$ Therefore, these two peaks are attributed to the reduction in two steps of $\mathrm{Co}_{3} \mathrm{O}_{4}$ particles. The reduction at $948 \mathrm{~K}$ is due to the reduction of $\mathrm{CoO}$ linked to silica.
The shift of the cobalt reduction peaks to higher temperatures demonstrates the intensity of the precursor/support interaction. Thus, these interactions are different in each support and this interaction is higher in $\mathrm{Al}_{2} \mathrm{O}_{3}$ than in the other supports. Storsæter et al. ${ }^{34}$ studied cobalt supported on $\gamma-\mathrm{Al}_{2} \mathrm{O}_{3}, \mathrm{TiO}_{2}$ and $\mathrm{SiO}_{2}$. They found that the precursor/support interaction increases in the following order: $\mathrm{TiO}_{2}<\mathrm{SiO}_{2}<\mathrm{Al}_{2} \mathrm{O}_{3} \cdot{ }^{34}$ Cassell et al. ${ }^{35}$ also reported that the interactions of the precursor catalysts with $\mathrm{Al}_{2} \mathrm{O}_{3}$ are stronger than with $\mathrm{SiO}_{2}$ because surface groups on $\mathrm{Al}_{2} \mathrm{O}_{3}$ have stronger Lewis acidities than those groups on $\mathrm{SiO}_{2}$.

Another important parameter obtained from the TPR is the degree of reduction of the cobalt oxide. However, different cobalt oxide species need different amounts of hydrogen to be reduced to the metallic form. Thus, to calculate the degree of reduction, it is necessary to know the cobalt species distribution in each catalyst. As several authors, ${ }^{32-37}$ we propose that in each catalyst two species may exist, crystalline $\mathrm{Co}_{3} \mathrm{O}_{4}$ particles and $\mathrm{CoO}$ species. The fraction of crystalline $\mathrm{Co}_{3} \mathrm{O}_{4}$ particles can be estimated from the hydrogen consumption in the first TPR peak, ${ }^{32}$ which corresponds to the reaction $\mathrm{Co}_{3} \mathrm{O}_{4}+\mathrm{H}_{2} \rightarrow 3 \mathrm{CoO}+\mathrm{H}_{2} \mathrm{O}$. Table 2 demonstrates the fraction of cobalt present as crystalline $\mathrm{Co}_{3} \mathrm{O}_{4}$ particles and $\mathrm{CoO}$ species. The catalyst with higher $\mathrm{CoO}$ species was $\mathrm{Co} / \mathrm{Al}_{2} \mathrm{O}_{3}$ followed by $\mathrm{Co} / \mathrm{SiO}_{2}, \mathrm{Co} / \mathrm{Nb}_{2} \mathrm{O}_{5}$ and $\mathrm{Co} / \mathrm{TiO}_{2}$.

Many authors ${ }^{28,34,38}$ used the theoretical molar ratio $1.33 \mathrm{H}_{2} / \mathrm{Co}$ (reduction of $\mathrm{Co}_{3} \mathrm{O}_{4}$ to $\mathrm{Co}$ ) to calculate the degree of reduction. In this case, the authors are assuming that all cobalt in unreduced catalyst is present as $\mathrm{Co}_{3} \mathrm{O}_{4}$ particles. However, the TPR results show that is not true for our catalysts (Table 2). In our work, it was used a theoretical ratio $\mathrm{H}_{2} /$ Co considering the fraction of $\mathrm{Co}_{3} \mathrm{O}_{4}$ and $\mathrm{CoO}$ in each sample. For example, in $\mathrm{Co} / \mathrm{Al}_{2} \mathrm{O}_{3}, 8 \%$ of the cobalt present in the catalyst is in the form of $\mathrm{Co}_{3} \mathrm{O}_{4}$, which requires a ratio of $1.33 \mathrm{~mol}$ of $\mathrm{H}_{2}$ to reduce $1 \mathrm{~mol}$ of $\mathrm{Co}$, and the other $92 \%$ is in the form of $\mathrm{CoO}$, which needs $1 \mathrm{~mol}$ of $\mathrm{H}_{2}$ to reduce $1 \mathrm{~mol}$ of Co. Thus, the $\mathrm{H}_{2} / \mathrm{Co}$ ratio needed to reduce $\mathrm{Co} / \mathrm{Al}_{2} \mathrm{O}_{3}$

Table 2. Distribution of cobalt species, $\mathrm{H}_{2} /$ Co ratio and degree of reduction of catalysts obtained from TPR analysis. Total and irreversible $\mathrm{H}_{2}$ chemisorption, dispersion and particle sizes of catalysts obtained from chemisorption analysis

\begin{tabular}{|c|c|c|c|c|c|c|c|c|}
\hline \multirow{3}{*}{ Catalyst } & \multicolumn{4}{|c|}{ TPR analysis } & \multicolumn{4}{|c|}{$\mathrm{H}_{2}$ chemisorption } \\
\hline & \multirow{2}{*}{$\begin{array}{l}\text { Fraction } \\
\text { of } \mathrm{Co}_{3} \mathrm{O}_{4}\end{array}$} & \multirow{2}{*}{$\begin{array}{l}\text { Fraction } \\
\text { of } \mathrm{Co}^{2+}\end{array}$} & \multirow{2}{*}{$\begin{array}{l}\mathrm{H}_{2} / \mathrm{Co} \\
\text { ratio }\end{array}$} & \multirow{2}{*}{$\begin{array}{c}\text { Degree of } \\
\text { reduction / \% }\end{array}$} & \multicolumn{2}{|c|}{$\begin{array}{c}\mathrm{H}_{2} \text { chemisorption / } \\
\left(\mu \mathrm{mol} \mathrm{g} \mathrm{g}_{\text {cat }}{ }^{-1}\right)^{*}\end{array}$} & \multirow[t]{2}{*}{$\mathrm{H} / \mathrm{Co} / \%$} & \multirow[t]{2}{*}{$\mathrm{d}_{\mathrm{p}} / \mathrm{nm}$} \\
\hline & & & & & Total & Irreversible & & \\
\hline $\mathrm{Co} / \mathrm{Al}_{2} \mathrm{O}_{3}$ & 0.08 & 0.92 & 1.0 & 31 & 7.2 & 3.1 & 6.8 & 14.7 \\
\hline $\mathrm{Co} / \mathrm{SiO}_{2}$ & 0.50 & 0.50 & 1.2 & 100 & 6.1 & 0 & 1.8 & 55.2 \\
\hline $\mathrm{Co} / \mathrm{Nb}_{2} \mathrm{O}_{5}$ & 0.59 & 0.41 & 1.2 & 82 & 0.3 & 0 & - & - \\
\hline $\mathrm{Co} / \mathrm{TiO}_{2}$ & 0.72 & 0.28 & 1.2 & 97 & 12.5 & 0 & 3.8 & 27.1 \\
\hline
\end{tabular}

$\mathrm{d}_{\mathrm{p}}$ : metallic particle diameter; $\mathrm{H} / \mathrm{Co}$ : molar relative dispersion, * (micromols of $\mathrm{H}_{2}$ per gram of catalyst). 
will be equal to 1.03 . Therefore, each catalyst has a different theoretical $\mathrm{H}_{2} / \mathrm{Co}$ ratio as show in Table 2 .

The degree of reduction after the TPR experiments was obtained from these theoretical ratio values. The reduction was close to $100 \%$ for catalysts supported on $\mathrm{SiO}_{2}, \mathrm{Nb}_{2} \mathrm{O}_{5}$ and $\mathrm{TiO}_{2}$, but it was quite low for the $\mathrm{Al}_{2} \mathrm{O}_{3}$ supported catalyst. This suggests an existence of irreducible species. Alumina supported cobalt catalysts have partial reducibility as cobalt aluminate species appears on the surface of support. ${ }^{39}$ Moreover, Ratnasamy and Knozinger ${ }^{41}$ found that a major fraction of $\mathrm{Co}$ in the oxide state is inside the alumina lattice and is not exposed to the gas phase.

For the catalysts supported on niobia and titania, in addition to the reduction of cobalt oxide species, a reduction of these supports was also expected when the temperature is higher than $773 \mathrm{~K}$ for niobia ${ }^{32}$ and higher than $573 \mathrm{~K}$ for titania. ${ }^{41}$ Thus, TPR analyses of the supports were used to verify this effect on the catalyst TPR profile. In this way, the degree of reduction of the catalysts was calculated taking into account the support reduction.

\section{$\mathrm{H}_{2}$ chemisorption}

Hydrogen chemisorption on the reduced catalyst was used to determine the dispersion and catalyst particle sizes. The results of hydrogen chemisorption for catalysts are shown in Table 2.

The total hydrogen chemisorption on the $\mathrm{Nb}_{2} \mathrm{O}_{5}$ supported catalyst was close to zero. This can be explained due to the migration of reduced species of the support to the metal surface, covering the metal and preventing it from hydrogen chemisorption. These results are consistent with those observed by Silva et $a l .{ }^{28}$

The same effect was also expected for $\mathrm{Co} / \mathrm{TiO}_{2} \cdot{ }^{41}$ However, this catalyst showed the highest total hydrogen chemisorption among the studied catalysts and the TPR analysis of the support did not show significant reduction. These results indicate that the migration of reduced species of the support to the surface of the metal in $\mathrm{Co} / \mathrm{TiO}_{2}$ catalysts was not as prevalent as in the $\mathrm{Co} / \mathrm{Nb}_{2} \mathrm{O}_{5}$ catalyst.

$\mathrm{Co} / \mathrm{Al}_{2} \mathrm{O}_{3}$ was the only catalyst that presented significant irreversible chemisorption (50\% of the total hydrogen adsorption), indicating that the hydrogen was more strongly adsorbed on this catalyst as compared to the other catalysts. Chemisorption is one of the most typical methods for determination of reduced particle size and dispersion. A corrected dispersion and particle size can be calculated based on the degree of reduction..$^{42}$ The degree of reduction was obtained from TPR analysis (Table 2). The particle size results were calculated considering total hydrogen chemisorption as recommended by Bartholomew ${ }^{17}$ and are given in Table 2 .
A high $\mathrm{H}_{2}$ chemisorption is a signature of a highly reduced cobalt surface which is responsible for the methane decomposition. However, for CNT production, besides the high specific surface area, it is desired that the metals are in the nanometer range of sizes and are uniforms. As stated before, there is a correlation between the size of the metal nanoparticles and the CNT diameter.

Note that the total $\mathrm{H}_{2}$ chemisorption is similar for both $\mathrm{Co} / \mathrm{Al}_{2} \mathrm{O}_{3}$ and $\mathrm{Co} / \mathrm{SiO}_{2}$, but the dispersion is very different resulting in different particle sizes. Particle dispersion is a function of the degree of reduction and since all catalysts have the same cobalt loading (4 wt.\%), the catalyst with a lower degree of reduction will result in higher dispersion and lower diameter size of the reduced cobalt particles. The particle size of the reduced cobalt supported in $\mathrm{Nb}_{2} \mathrm{O}_{5}$ could not be calculated due to the coating of cobalt particles by the reduced species of the support. The cobalt diameter in $\mathrm{Co} / \mathrm{TiO}_{2}$ catalyst was calculated considering that this effect was very small for this catalyst.

For CO chemisorption on Co supported catalysts, Bartholomew ${ }^{17}$ recommended the use of irreversible chemisorption to estimate the particle size. Among all studied catalysts, only $\mathrm{Co} / \mathrm{Al}_{2} \mathrm{O}_{3}$ and $\mathrm{Co} / \mathrm{TiO}_{2}$ catalysts showed significant irreversible $\mathrm{CO}$ chemisorption, 11 and $6 \mu \mathrm{mol} \mathrm{g}{ }_{\text {cat }}^{-1}$, respectively.

\section{Methane conversion}

Figure $4 \mathrm{a}$ shows the methane conversion as a function of the number of pulses and Figure $4 \mathrm{~b}$ shows the hydrogen signal obtained from the methane decomposition in each pulse as a function of the time.

$\mathrm{Co} / \mathrm{Al}_{2} \mathrm{O}_{3}$ was more active than the other catalysts. It is interesting that the same order of the support effect has been found for similar support series (alumina $>$ silica $>$ magnesia) on methane decomposition for cobalt ${ }^{43}$ and palladium ${ }^{44}$ catalysts. $\mathrm{Co} / \mathrm{Nb}_{2} \mathrm{O}_{5}$ catalyst showed very low activity. This can be explained due to the covering of the cobalt surface by reduced species of the support.

The $\mathrm{Co} / \mathrm{SiO}_{2}$ catalyst showed an increase in hydrogen produced during the methane pulses (Figure $4 \mathrm{~b}$ ). This result indicates that there was a fraction of unreduced cobalt species after the reduction step, which was reduced in the presence of methane at high temperature.

\section{Characterization of carbon nanotubes}

\section{Raman spectroscopy}

Raman spectroscopy is an excellent technique for characterizing the structure of CNT. The G tangential mode around $1590 \mathrm{~cm}^{-1}$ was used to identify the presence 

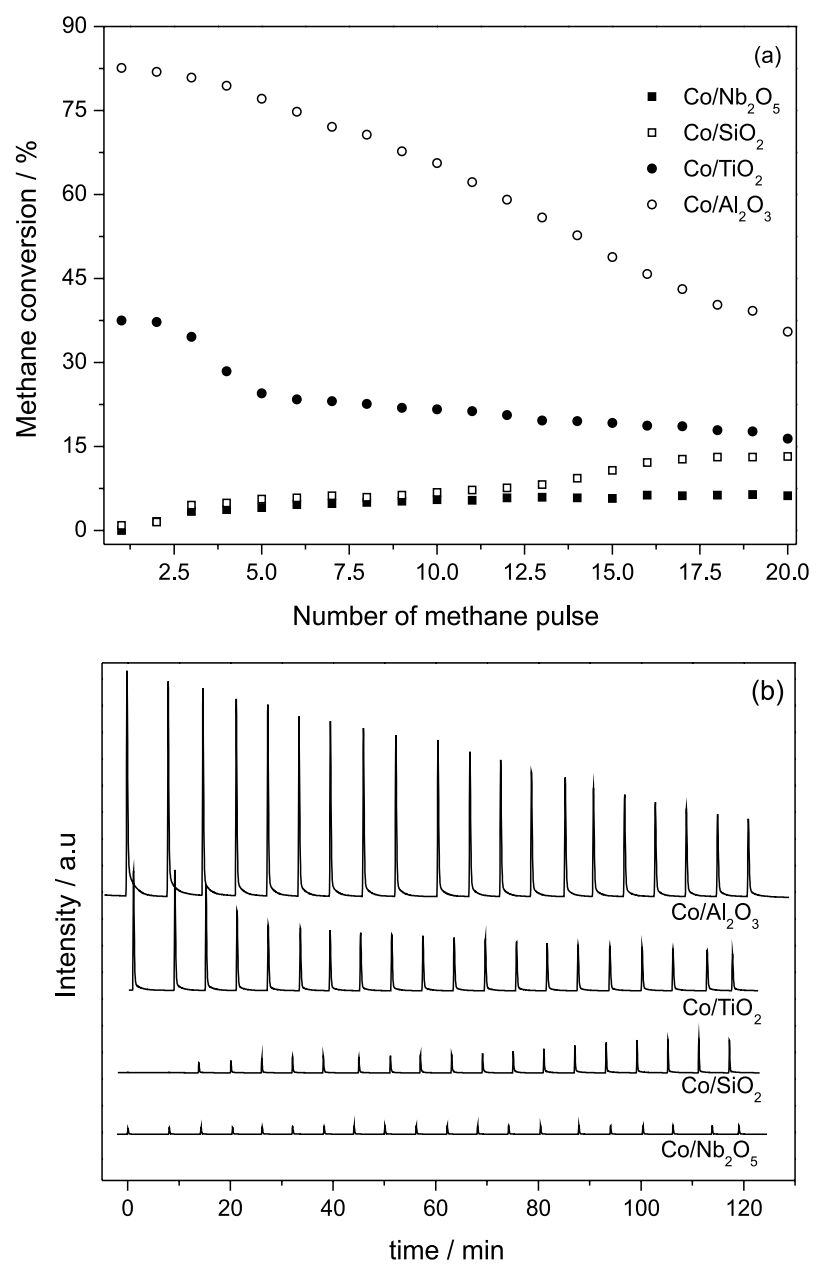

Figure 4 (a) Methane conversion in function of the pulses and (b) hydrogen formed during the methane decomposition reaction in function of the time, the intensity of the signal was divided for the mass of catalyst used in each reaction. The reaction temperature was $973 \mathrm{~K}$, and each pulse enclosed $0.5 \mathrm{ml}$ of $\mathrm{CH}_{4}$ at $393 \mathrm{~K}$.

of ordered carbon like graphite and carbon nanotubes, both having hybridized $\mathrm{sp}^{2}$ carbon system..$^{5}$

The $\mathrm{D}$ band around $1350 \mathrm{~cm}^{-1}$ is associated with defects or amorphous carbon, giving an indication of the amount of disordered carbon..$^{14,45}$ Therefore, the ratio of the $\mathrm{D}$ and $\mathrm{G}$ band intensities $(\mathrm{D} / \mathrm{G})$ is used as qualitative measurement for the formation of undesired forms of carbon. ${ }^{46,47}$

Figure 5 shows the Raman spectra obtained from the carbon deposits formed on the catalysts. All samples showed $\mathrm{D}$ and $\mathrm{G}$ bands, except for the $\mathrm{Co} / \mathrm{Nb}_{2} \mathrm{O}_{5}$ sample. This one did not show $\mathrm{G}$ or $\mathrm{D}$ bands indicating that no significant amount of carbon was deposited on the catalyst. For the other samples, it can be observed that the intensities of the D and $\mathrm{G}$ bands in each sample are equivalents. These profiles are typical from MWNT. However, the D/G ratio and the width at a half height of the $\mathrm{G}$ peak are smaller for $\mathrm{Co} / \mathrm{TiO}_{2}$ as compared to $\mathrm{Co} / \mathrm{SiO}_{2}$ and $\mathrm{Co} / \mathrm{Al}_{2} \mathrm{O}_{3}$, indicating the presence of tubes with lower walls. Table 3 summarizes these results.

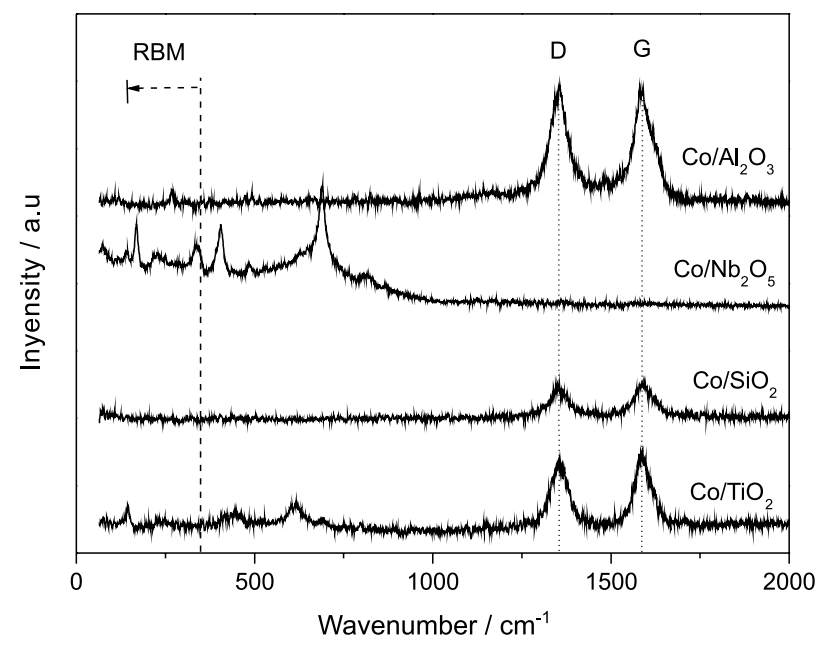

Figure 5. Raman spectrum of the carbon deposits on catalysts produced by methane chemical vapor deposition. RBM: radial breathing mode.

The presence of the radial breathing mode (RBM) between 140 and $350 \mathrm{~cm}^{-1}$ gives direct information about the SWNT diameter. The SWNT diameter can be determined according to the expression $\mathrm{d}=(238 / \lambda)^{1.075}$ developed by Rols et al. ${ }^{47}$ where $\mathrm{d}$ is the SWNT diameter (in $\mathrm{nm}$ ) and $\lambda$ is the wavenumber (in $\mathrm{cm}^{-1}$ ).

The $\mathrm{Co} / \mathrm{Nb}_{2} \mathrm{O}_{5}$ and $\mathrm{Co} / \mathrm{TiO}_{2}$ samples showed peaks at $\mathrm{RBM}$ range, but only the $\mathrm{Co} / \mathrm{Al}_{2} \mathrm{O}_{3}$ sample is associated

Table 3. Raman spectroscopy and TPO data of the samples on the support. The diameter of SWNT and FWHM were obtained from Raman analysis. The carbon yield and the selectivity of the carbon deposits were calculated from TPO analysis

\begin{tabular}{|c|c|c|c|c|c|c|c|c|}
\hline \multirow{3}{*}{ Catalyst } & \multicolumn{4}{|c|}{ Raman analysis } & \multicolumn{4}{|c|}{ TPO analysis } \\
\hline & \multicolumn{2}{|c|}{ SWNT } & \multirow{2}{*}{$\begin{array}{c}\text { FWHM } / \mathrm{cm}^{-1} \\
(\mathrm{G})\end{array}$} & \multirow{2}{*}{$\begin{array}{c}\mathrm{D} / \mathrm{G} \\
\text { intensity ratio }\end{array}$} & \multirow{2}{*}{ Yield / \% } & \multirow{2}{*}{$\begin{array}{l}\text { Amorphous } \\
\text { carbon / \% }\end{array}$} & \multirow{2}{*}{ SWNT / \% } & \multirow{2}{*}{ MWNT / \% } \\
\hline & $\mathrm{v} / \mathrm{cm}^{-1}$ & $\mathrm{~d} / \mathrm{nm}$ & & & & & & \\
\hline $\mathrm{Co} / \mathrm{Al}_{2} \mathrm{O}_{3}$ & 267 & 0.9 & 58 & 1.02 & 34.1 & 30.6 & 43 & 26.4 \\
\hline $\mathrm{Co} / \mathrm{Nb}_{2} \mathrm{O}_{5}$ & - & - & - & - & 0.5 & - & - & - \\
\hline $\mathrm{Co} / \mathrm{TiO}_{2}$ & - & - & 46 & 0.88 & 17 & 20 & 80 & 0 \\
\hline $\mathrm{Co} / \mathrm{SiO}_{2}$ & - & - & 56 & 0.92 & 3.7 & 1.2 & 35.4 & 63.4 \\
\hline
\end{tabular}

FWHM: full-width at half maximum. 
with the presence of SWNT. In the $\mathrm{Co} / \mathrm{Nb}_{2} \mathrm{O}_{5}$ sample, the peak at $168.5 \mathrm{~cm}^{-1}$ is due to the TT- $-\mathrm{Nb}_{2} \mathrm{O}_{5}$ crystalline phase..$^{48} \mathrm{In}$ the same way, the peak at $146 \mathrm{~cm}^{-1}$ on $\mathrm{Co} / \mathrm{TiO}_{2}$ catalyst cannot be directly associated with the presence of SWNT, as this peak is associated with the presence of $\mathrm{TiO}_{2}$ rutile phase. ${ }^{49}$

From the RBM peak observed for the carbon deposits on $\mathrm{Co} / \mathrm{Al}_{2} \mathrm{O}_{3}$, it was possible to evaluate the size of the SWNT diameter. These results are show in Table 3.

In spite of all information that Raman spectroscopy can provide, a quantitative amount of the different types of carbon deposited on the catalysts cannot be obtained by this technique. For quantifying the amount of the different types of carbon present on the catalyst, a TPO analysis is necessary. ${ }^{3}$

\section{Temperature programmed oxidation (TPO)}

From the TPO results, it was possible to obtain a quantitative characterization of the different types of carbon present on the catalysts since they oxidize at different temperatures. ${ }^{3}$ Amorphous carbon is the first species to be oxidized and SWNT are oxidized in a narrow temperature range, which occurs above the oxidation temperature of amorphous carbon and below the oxidation temperature of MWNT and graphite. The TPO profiles of the carbon species present on the catalysts are illustrated in Figure 6.

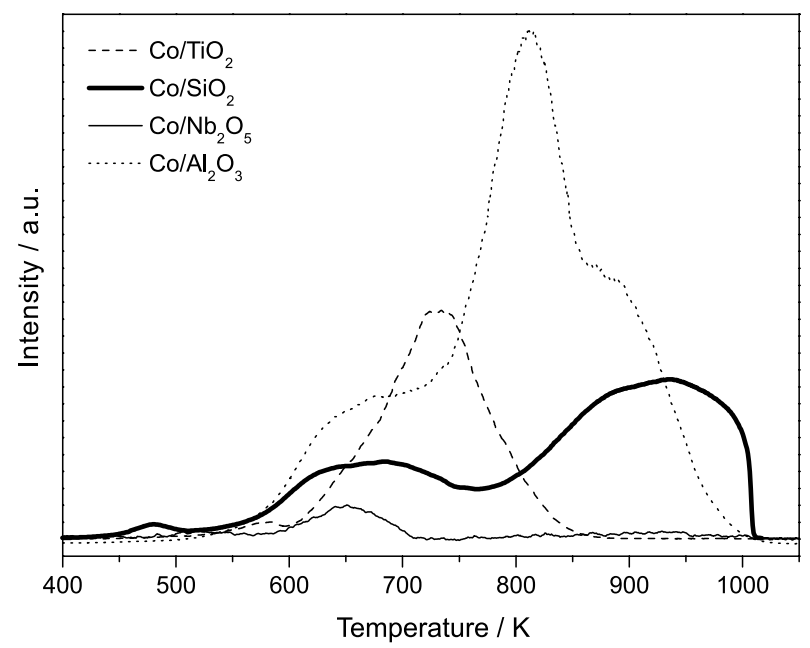

Figure 6. TPO profiles of carbon species present on catalysts. The oxidation was conducted under $5 \% \mathrm{O}_{2} / \mathrm{He}$, using a heating rate of $10 \mathrm{~K} \mathrm{~min}^{-1}$.

The TPO profiles of the carbon species present on $\mathrm{Co} / \mathrm{SiO}_{2}$ catalyst clear showed this different oxidation temperature of each species. The first peak at $479 \mathrm{~K}$ is associated with the oxidation of amorphous carbon, the second peak at $680 \mathrm{~K}$ is associated with oxidation of
SWNT and the third peak at $931 \mathrm{~K}$ is associated with oxidation of MWNT or graphite. ${ }^{15}$

The $\mathrm{Co} / \mathrm{Al}_{2} \mathrm{O}_{3}$ catalyst showed high evolution of $\mathrm{CO}_{2}$ on TPO analyses due its high activity in the methane decomposition as previously demonstrated by the $\mathrm{CH}_{4}$ pulses. The $\mathrm{CO}_{2}$ peaks are very close to each other. Therefore, the quantification of the carbon species was made by deconvolution of the TPO profile. The integrated areas under each peak represent the selectivity of each carbon species. The TPO profile of this sample demonstrates the low selectivity of the $\mathrm{Co} / \mathrm{Al}_{2} \mathrm{O}_{3}$ catalyst due to the large range of the oxidation temperatures, corresponding to different species (Table 3).

For the $\mathrm{Co} / \mathrm{Nb}_{2} \mathrm{O}_{5}$ catalyst, only a small peak at $653 \mathrm{~K}$ was observed. This peak may be associated with the oxidation of amorphous carbon since no CNT was observed in SEM images (Figure 7b).
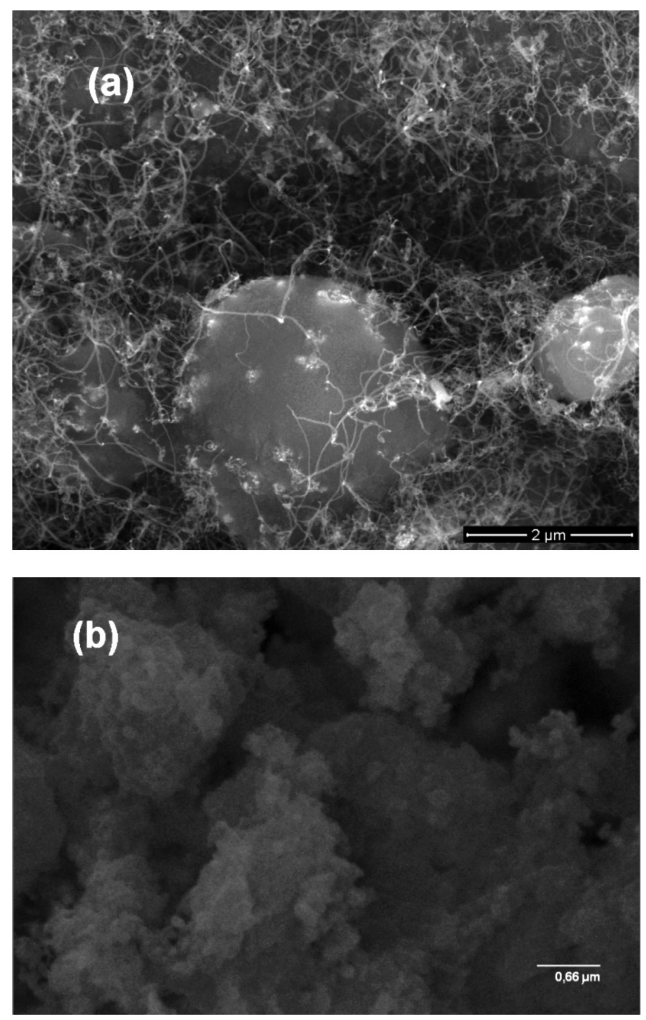

Figure 7. SEM image of CNT sample prepared on (a) $\mathrm{Co} / \mathrm{Al}_{2} \mathrm{O}_{3}$ catalyst and (b) $\mathrm{Co} / \mathrm{Nb}_{2} \mathrm{O}_{5}$ catalyst. Sample was grown at $973 \mathrm{~K}$ under $200 \mathrm{sccm}$ of $\mathrm{CH}_{4}$ for $30 \mathrm{~min}$.

The total carbon yield was defined as the mass of carbon deposited per mass of catalyst. The mass of carbon present in each sample was determined by the evolution of $\mathrm{CO}_{2}$. There was always $\mathrm{O}_{2}$ in excess to avoid the formation of carbon monoxide.

$\mathrm{Co} / \mathrm{Al}_{2} \mathrm{O}_{3}$ presented the highest total yield $(34.1 \%$ ), followed by $\mathrm{Co} / \mathrm{TiO}_{2}, \mathrm{Co} / \mathrm{SiO}_{2}$ and $\mathrm{Co} / \mathrm{Nb}_{2} \mathrm{O}_{5}$, respectively. 
The most selective catalyst toward SWNT was $\mathrm{Co} / \mathrm{TiO}_{2}$ Approximately $80 \%$ of the carbon in this sample oxidized in the range of the SWNT oxidation., ${ }^{2,15,50}$

The oxidation reaction in TPO analyses may be catalyzed by the cobalt particles, shifting the peak position to lower temperatures. ${ }^{4}$ It explains the differences in the temperature peaks observed for the same carbon species in different catalysts. For example, the SWNT oxidation temperature peak in $\mathrm{Co} / \mathrm{TiO}_{2}$ catalyst is lower than in $\mathrm{Co} / \mathrm{Al}_{2} \mathrm{O}_{3}$. This occurred because the amount of cobalt particles exposed to reaction is higher in $\mathrm{Co} / \mathrm{TiO}_{2}$ than in $\mathrm{Co} / \mathrm{Al}_{2} \mathrm{O}_{3}$. As seen before with TPR analysis, $\mathrm{Co} / \mathrm{Al}_{2} \mathrm{O}_{3}$ is the catalyst with the lower degree of reduction and a major fraction of $\mathrm{Co}$ is inside the alumina lattice and is not exposed to the gas phase.

\section{Scanning electron microscopy (SEM)}

SEM has been used to identify the various carbon species present in samples. ${ }^{51}$ The SEM image in Figure 7a shows a high density of CNT production on $\mathrm{Co} / \mathrm{Al}_{2} \mathrm{O}_{3}$ catalysts and there is a larger distribution of the diameter size (from $7 \mathrm{~nm}$ to $35 \mathrm{~nm}$, approximately), suggesting the presence of SWNT and MWNT. All these analyses are in agreement with the TPO results, which show higher yield of CNT (34.1\%) and the presence of amorphous carbon, SWNT and MWNT. It was also able to verify that the base-growth mode dominates in $\mathrm{Co} / \mathrm{Al}_{2} \mathrm{O}_{3}$ catalyst. In this growth mode, cobalt particles interact strongly with the support and remain trapped during growth. ${ }^{52}$

In contrast to Figure 7a, the SEM image of $\mathrm{Co} / \mathrm{Nb}_{2} \mathrm{O}_{5}$ after the reaction step (Figure $7 \mathrm{~b}$ ) did not show the presence of CNT or carbon filaments, confirming the TPO and Raman results.

\section{Catalyst properties and CNT production}

The results reported in this work show the notable influence that the support has on the methane decomposition and CNT production. For $\mathrm{Co} / \mathrm{TiO}_{2}$, it was not possible to detect $\mathrm{Co}_{3} \mathrm{O}_{4}$ XRD peaks due its relatively high Co dispersion. This suggests that the crystallite size of $\mathrm{Co}_{3} \mathrm{O}_{4}$ on $\mathrm{TiO}_{2}$ was probably below the lower limit for XRD detection. In this way, the size of $\mathrm{Co}_{3} \mathrm{O}_{4}$ particles supported on $\mathrm{TiO}_{2}$ should be smaller than those supported on $\mathrm{SiO}_{2}$ and $\mathrm{Al}_{2} \mathrm{O}_{3}$. However, the particle size obtained from chemisorption analysis was $27 \mathrm{~nm}$. These results suggest that part of the cobalt particles was covered by the reduced support species after reduction step. This effect known as strong metal support effect (SMSI) was also observed by Li et al. ${ }^{41}$

The cobalt particle diameter for the $\mathrm{Co} / \mathrm{SiO}_{2}$ catalyst obtained from chemisorption was considerably larger than the value obtained by XRD. The incomplete reduction of the cobalt oxide species after the reduction step at $973 \mathrm{~K}$ seems to be the main reason for the low amount of $\mathrm{H}_{2}$ chemisorption on this catalyst resulting in an incorrect particle diameter value. This is consistent with the methane decomposition pulse experiments, in which a fraction of the cobalt species was not reduced after the reduction step, resulting in a lack of hydrogen production in the initial pulses.

A direct correlation between the average pore diameter and the average cobalt diameter for catalysts has been previously reported. Saib et al. ${ }^{53}$ found that the cluster size increases with increasing pore diameter of the $\mathrm{SiO}_{2}$ support. However, contradictory results on the dependence of the size of $\mathrm{Co}_{3} \mathrm{O}_{4}$ clusters and the pore diameter were found in this work. The results obtained from physisorption and XRD showed that the $\mathrm{TiO}_{2}$ had larger pore diameter than the $\mathrm{SiO}_{2}$ and $\mathrm{Al}_{2} \mathrm{O}_{3}$ supports, while the size of $\mathrm{Co}_{3} \mathrm{O}_{4}$ particles supported on $\mathrm{TiO}_{2}$ may be smaller than those supported on $\mathrm{SiO}_{2}$ and $\mathrm{Al}_{2} \mathrm{O}_{3}$. A comparable result was also found by Storsæter et al. ${ }^{34}$ They studied the distribution of cluster and particle sizes of $\mathrm{Co}_{3} \mathrm{O}_{4}$ on the $\mathrm{SiO}_{2}, \mathrm{Al}_{2} \mathrm{O}_{3}$ and $\mathrm{TiO}_{2}$ supports and reported that $\mathrm{Co}_{3} \mathrm{O}_{4}$ particles were distributed more uniformly over the $\mathrm{TiO}_{2}$ support than on $\mathrm{SiO}_{2}$ and $\mathrm{Al}_{2} \mathrm{O}_{3}$. They concluded that $\mathrm{Co}_{3} \mathrm{O}_{4}$ particles will exist as agglomerates up to a certain pore size, beyond which no agglomeration will occur. ${ }^{34}$

The average $\mathrm{Co}_{3} \mathrm{O}_{4}$ particle diameters on $\mathrm{Co} / \mathrm{Al}_{2} \mathrm{O}_{3}$ and $\mathrm{Co} / \mathrm{SiO}_{2}$ catalysts estimated by XRD analysis were larger than the average pore diameter. In this case, a large fraction of the particles was not found to be inside the single pores, but rather on the outside and occupying interconnected pore cavities as founded by Storsæter et al. ${ }^{34}$

Since there is a correlation between the size of the metal nanoparticles and the CNT diameter, the control of the distribution of nanoparticle size is an important parameter in CNT production. A large particle size distribution will produce different CNT and other forms of carbon and their oxidation will occur at different temperatures. The carbon deposits on $\mathrm{Co} / \mathrm{TiO}_{2}$ sample showed the narrowest oxidation temperature range $(410 \mathrm{~K})$. This result demonstrates the regularity of the $\mathrm{CNT}$ yield with $\mathrm{Co} / \mathrm{TiO}_{2}$ catalysts. The $\mathrm{Co} / \mathrm{Al}_{2} \mathrm{O}_{3}$ and $\mathrm{Co} / \mathrm{SiO}_{2}$ samples showed a broad oxidation temperature range, $560 \mathrm{~K}$ for the carbon deposited on $\mathrm{Co} / \mathrm{SiO}_{2}$ catalyst and $500 \mathrm{~K}$ for the carbon deposited on $\mathrm{Co} / \mathrm{Al}_{2} \mathrm{O}_{3}$ catalysts. These results suggest that the $\mathrm{Co}_{3} \mathrm{O}_{4}$ particle sizes were distributed relatively more uniformly over the $\mathrm{TiO}_{2}$ support than on $\mathrm{SiO}_{2}$ and $\mathrm{Al}_{2} \mathrm{O}_{3}$.

From total $\mathrm{H}_{2}$ chemisorption, it was possible to estimate the number of active sites for each catalyst. The catalyst that showed more active sites was $\mathrm{Co} / \mathrm{TiO}_{2}\left(25 \mu \mathrm{mol} \mathrm{Co} \mathrm{g}_{\mathrm{cat}}{ }^{-1}\right)$ 
followed by $\mathrm{Co} / \mathrm{Al}_{2} \mathrm{O}_{3}\left(14.4 \mu \mathrm{mol} \mathrm{Co} \mathrm{g}_{\text {cat }}{ }^{-1}\right)$ and $\mathrm{Co} / \mathrm{SiO}_{2}$ $\left(12.2 \mu \mathrm{mol} \mathrm{Co} \mathrm{g}_{\text {cat }}{ }^{-1}\right)$. However, the $\mathrm{Co} / \mathrm{Al}_{2} \mathrm{O}_{3}$ was the catalyst that showed higher methane conversion (Figure 4). The activity for the $\mathrm{Co} / \mathrm{TiO}_{2}$ catalyst was probably influenced by the coating of cobalt particles by the reduced species of the support. This result is supported by the low $\mathrm{H} / \mathrm{Co}$ ratio (3.8\%) found in chemisorption analysis.

From TPR and chemisorption analysis, it was concluded that the reducibility of the Co species is strongly influenced by the support. The degree of Co reduction was smallest for the $\mathrm{Co} / \mathrm{Al}_{2} \mathrm{O}_{3}$ catalyst, only $31 \%$ of the cobalt was reduced to $\mathrm{Co}^{0}$. In the others, $79 \%$ of the cobalt is in the form of cobalt aluminate or inside the alumina lattice. Another interesting result is that $\mathrm{Co} / \mathrm{Al}_{2} \mathrm{O}_{3}$ was the only catalyst that showed irreversible $\mathrm{H}_{2}$ chemisorption, indicating a strong interaction between the metallic cobalt particle and hydrogen. This interaction should influence the activity of the catalyst since the methane decomposition on cobalt particles is the first step for CNT production. ${ }^{24}$ Moreover, the cobalt/support interactions determine the mode of carbon nanotube growth. ${ }^{35}$ Weak interactions (like in the $\mathrm{Co} / \mathrm{SiO}_{2}$ catalyst) yield tip-grown CNT. In this mode, the cobalt particles are more exposed to the methane flow, allowing the carbon nanotubes to grow for a longer time, whereas strong interactions (like in the $\mathrm{Co} / \mathrm{Al}_{2} \mathrm{O}_{3}$ catalyst) lead to base-growth, limiting the access of methane to cobalt particles deactivating the catalysts. These results are show in Figure 4.

Cassell et al..$^{35}$ attributed, at least in part, that a more open textural support structure is responsible for an increase in yield due to more efficient diffusion of reactants and intermediate hydrocarbon species. This effect was very small in the catalysts studied in this work. There was not any correlation between the pore structure and the total yield of carbon on CNT reaction. Figure 8a shows the total carbon yield as a function of average pore diameter of the catalysts. Thus, the Co surface area seems to be the main effect responsible for the increase in the activity of the catalysts (Figure 8b).

A fundamental step needed for the production of CNT is a trustworthy characterization of the type and amount of carbon deposited on a given sample. The characterization and quantification of the carbon deposited was done using Raman spectroscopy, TPO and SEM techniques. These techniques united allowed identifying the different carbon species present on the catalysts. It can be concluded that the most selective catalyst toward SWNT was $\mathrm{Co} / \mathrm{TiO}_{2}$. Most of the oxidized carbon (in its TPO profile) oxidized in the range of SWNT oxidation. The Raman spectroscopy analysis agrees with this results showing lower FWHM (full-width at half maximum) and
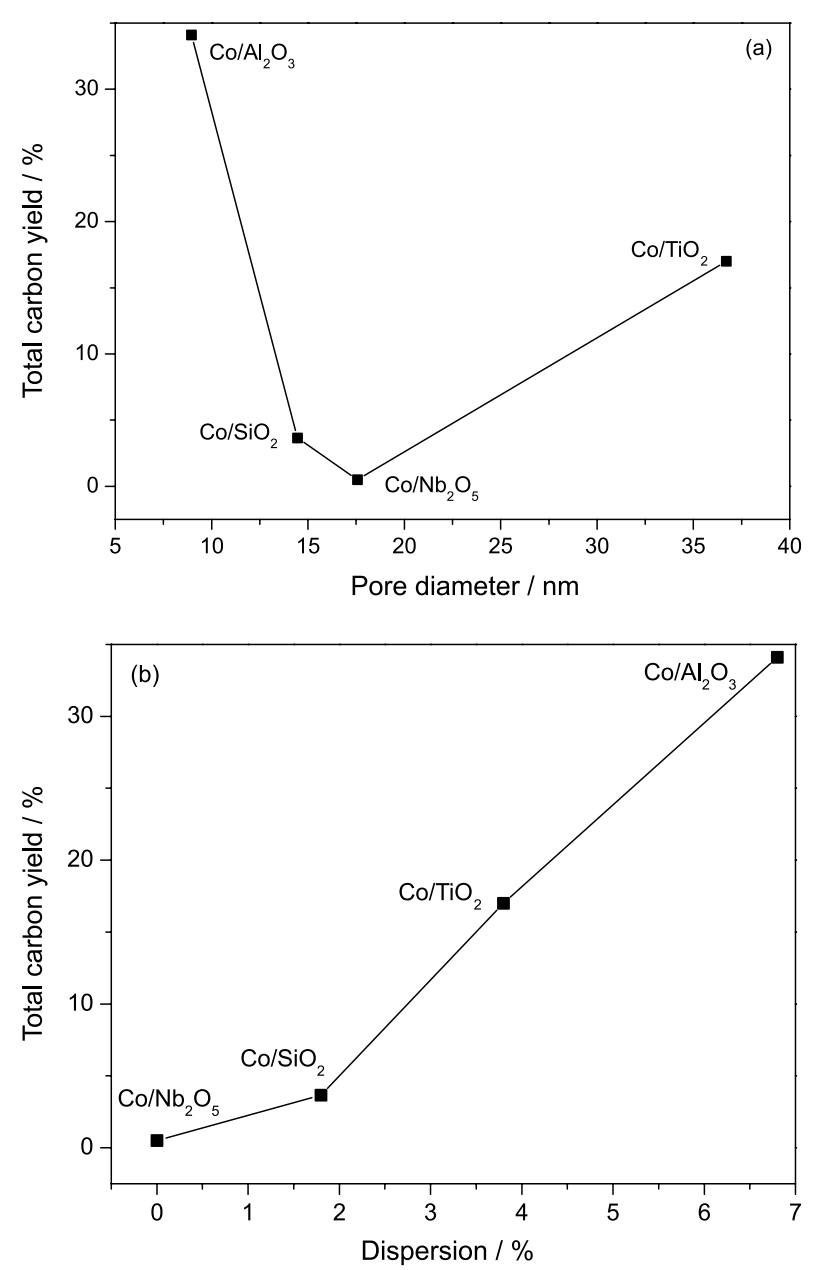

Figure 8. (a) Correlation between total carbon yield and the average pore diameter of catalysts and (b) correlation between total carbon yield and Co dispersion. The total carbon yield was obtained from TPO analysis and is defined as mass of carbon deposits per mass of catalyst.

$\mathrm{D} / \mathrm{G}$ ratio. However, the $\mathrm{D} / \mathrm{G}$ value (0.88) suggests the presence of a small number of tubes with few walls. The $\mathrm{Co} / \mathrm{Al}_{2} \mathrm{O}_{3}$ catalyst was the most active catalyst, with a yield of $34.1 \%$. On the other hand, this catalyst produced different forms of carbon. This lack of selectivity may be attributed to the broad distribution of the cobalt particle size. The particle size obtained from Scherrer equation $(16.8 \mathrm{~nm})$ is just an average of the most usual particle size. It does not mean that there is not different particle size. The Raman experiments showed the presence of RBM peak, which is typical of SWNT. Therefore, it means that there are SWNT on this sample and SWNT can only grow from small particles. Moreover, the TPO results showed an oxidation of different carbon species (amorphous, SWNT and MWNT) which are formed from different metallic particle sizes. ${ }^{26,54}$

From the results, it was confirmed that the increase in the activity of the catalyst can be mostly attributed to the total amount of surface Co species, which are strongly 
affected by the support properties, as far as reducibility and precursor/support interactions are concerned. The selectivity toward CNT was in part dependent on the cobalt particle size, which was also dependent on the textural propertie of the support. For better control of the cobalt particles size distribution is necessary that the support has large pore diameters and high specific surface area to avoid the agglomeration of the cobalt particles.

\section{Conclusions}

A narrow size distribution of the cobalt particles is necessary to increase the selectivity of CNT formation. The cobalt particle size distribution depended on the nature, specific surface area and pore diameter distribution of the support. Supports with high specific surface area but without large pore diameter $\left(\mathrm{Al}_{2} \mathrm{O}_{3}\right.$ and $\left.\mathrm{SiO}_{2}\right)$ can lead to agglomeration of cobalt particles on 4 wt.\% supported catalyst. This agglomeration will lead to large size distribution of the cobalt particles producing different carbon species. A support with large pore diameter and a strong interaction between cobalt oxide particles and its support can avoid the agglomeration of cobalt particles. Thus, $\mathrm{Co} / \mathrm{TiO}_{2}$ catalyst exhibited a high selectivity toward SWNT production, which results from the uniform size distribution of the Co particles.

The total activity of the catalyst in methane decomposition and consequently in CNT yield was dependent on the total amount of surface Co species. This way, $\mathrm{Co} / \mathrm{Al}_{2} \mathrm{O}_{3}$ presented the highest activity, and in the case of $\mathrm{Co} / \mathrm{Nb}_{2} \mathrm{O}_{5}$ and $\mathrm{Co} / \mathrm{TiO}_{2}$ catalysts, the migration of reduced species of the support to the metal surface inhibited their activity.

\section{Acknowledgements}

We would like to thank the Coordenação de Aperfeiçoamento de Pessoal de Nível Superior (CAPES) for financial support, the Instituto Nacional de Tecnologia (INT) for XRD measurements, the Instituto Militar de Engenharia (IME) for SEM images and to the Instituto Nacional de Metrologia, Normalização e Qualidade Industrial (INMETRO) for Raman measurements.

\section{References}

1. Cheng, H. M.; Li, F.; Su, G.; Pan, H. Y.; He, L. L.; Sun, X.; Dresselhaus, M. S.; Appl. Phys. Lett. 1998, 72, 3282.

2. Su, M.; Zheng, B.; Liu J.; Chem. Phys. Lett. 2000, 322, 321.

3. Herrera, J. E.; Balzano, L.; Borgna, A.; Alvarez, W. E.; Resasco, D. E.; J. Catal. 2001, 204, 129.
4. Herrera, J. E.; Resasco D. E.; Chem. Phys. Lett. 2003, 376, 302.

5. Grimm, D.; Gruneis, A.; Kramberger, C.; Chem. Phys. Lett 2006, $428,416$.

6. Qian, W. Z.; Tian, T.; Guo, C. Y.; J. Phys. Chem. C 2008, 112, 7588.

7. Nagaraju, N.; Fonseca, A.; Konya, Z.; Nagy, J. B.; J. Mol. Catal A: Chem. 2002, 181, 57.

8. Chiang, W. H.; Sankaran, R. M.; Nat. Mater. 2009, 8, 882.

9. Irurzun, V. M.; Tan, Y. Q.; Resasco, D. E.; Chem. Mater. 2009, 21,2238 .

10. Liu, Z. M.; Han, B. X.; Adv. Mater. 2009, $21,825$.

11. Meshot, E. R.; Plata, D. L.; Tawfick, S.; Zhang, Y. Y.; Verploegen, E. A.; Hart, A. J.; ACS Nano 2009, 3, 2477.

12. Sugime, H.; Noda S.; Maruyama, S.; Yamaguchi, Y.; Carbon 2009, 47, 234.

13. Dupuis, A. C.; Progr. Mater. Sci. 2005, 50, 929.

14. Saito, R.; Fujita, M.; Dresselhaus, G.; Dresselhaus, M. S.; Appl. Phys. Lett. 1992, 60, 2204.

15. Kitiyanan, B.; Alvarez, W. E.; Harwell, J. H.; Resasco, D. E.; Chem. Phys. Lett. 2000, 317, 497.

16. Zowtiak, J. M.; Bartholomew, C. H.; J. Catal. 1983, 83, 107.

17. Bartholomew, C. H.; Catal. Lett. 1990, 7, 27.

18. Klug, H. P.; Alexander, L. E.; In X-ray Difraction Procedures for Polycrystalline and Amorphous Materials, 2nd ed.; John Wiley \& Sons: New York, 1974

19. Ko, E. I.; Weissman, J. G.; Catal. Today 1990, 8, 27.

20. Agoudjil, N.; Benkacem, T.; Desalination 2007, 206, 531.

21. Park, J. W.; Jeong, J. H.; Yoon, W. L.; Jung, H.; Lee, H. T.; Lee, D. K.; Park, Y. K.; Rhee, Y. W.; Appl. Catal: A Gen. 2004, 274, 25.

22. Dal, H. J.; Rinzler, A. G.; Nikolaev, P.; Thess, A.; Colbert, D. T.; Smalley R. E.; Chem. Phys. Lett. 1996, 260, 471.

23. Willems, I.; Konya, Z.; Colomer, J. F.; Chem. Phys. Lett. 2000, 317, 71 .

24. Li, Y. M.; Kim, W.; Zhang, Y. G.; Rolandi, M.; Wang, D. W.; Dai, H. J.; J. Phys. Chem. B 2001, 105, 11424.

25. Cheung, C. L.; Kurtz, A.; Park, H.; Lieber, C. M.; J. Phys. Chem. B 2002, 106, 2429.

26. Zhang, W. D.; Wen, Y.; Tjiu, W.C.; Xu, G. Q.; Gan, L. M.; Appl. Phys. A: Mater Sci. Process. 2002, 74, 419.

27. Zhang, Y.; Li, Y.; Kim, W.; Wang, D.; Dai, H.; Appl. Phys. A: Mater. Sci. Process. 2002, 74, 325.

28. Silva, R.; Schmal, M.; Frety, R.; Dalmon, J. A.; J. Chem. Soc., Far. Trans. 1993, 89, 3975.

29. Jeong, S. H.; Hwang, H. Y.; Lee, K. H.; Jeong, Y.; Appl. Phys. Lett. 2001, 78, 2052.

30. Duesberg, G. S.; Graham, A. P.; Liebau, M.; Nano Lett. 2003, 3, 257.

31. Fan, S. S.; Liang, W. J.; Dang, H. Y. Franklin, N.; Tombler, T.; Chapline, M.; Dai, H. J. ; Physica E 2000, 8, 179. 
32. Noronha, F. B.; Perez, C. A.; Schmal, M.; Frety, R.; Phys. Chem. Chem. Phys. 1999, 1, 2861.

33. Kraum, M, Baerns, M.; Appl. Catal., A 1999, 186, 189; Madikizela, N. N.; Coville, N. J.; Mol Catal A: Chem. 2002, 181, 129; Kalala, J.; Coville, N. J.; Diane, H.; Glasser, D.; Jewell, L. L.; Fuel 2007, 86, 73.

34. Storsæter, S.; Totdal, B.; Walmsley, J. C.; Tanem, B. S.; Holmen, A.; J. Catal. 2005, 236, 139.

35. Cassell, A. M.; Raymakers, J. A.; Kong, J.; Dai, H. J.; J. Phys. Chem. B 1999, 103, 6484.

36. Chin, R. L.; Hercules, D. M.; J. Phys. Chem. 1982, 86, 360.

37. Ho, S. W.; Cruz, J. M.; Houalla, M.; Hercules, D. M.; J. Catal. 1992, 135, 173.

38. Hinchiranan, S.; Zhang, Y.; Nagamori, S.; Vitidsant, T.; Tsubaki, N.; Fuel Process. Technol. 2008, 89, 455.

39. Zhang, J. L.; Chen, J. G.; Ren, J.; Sun, Y. H; Appl. Catal. A: Gen. 2003, 243, 121.

40. Ratnasamy, P.; Knozinger, H.; J. Catal. 1978, 54, 55.

41. Li, Y. Z.; Fan, Y. N.; Yang, H. P.; Chem. Phys. Lett. 2003, 372, 160.

42. Storsaeter, S.; Borg, O.; Blekkan, E. A.; Holmen, A.; J. Catal. 2005, 231, 405.

43. Avdeeva, L. B.; Kochubey, D. I.; Shaikhutdinov, S. K.; Appl. Catal. A: Gen. 1999, 177, 43.
44. Boskovic, G.; Smith, K. J.; Catal. Today 1997, 37, 25.

45. Alvarez, W. E.; Pompeo, F.; Herrera, J. E.; Balzano, L.; Resasco, D. E.; Chem. Mater. 2002, 14, 1853.

46. Bandow, S.; Asaka S.; Saito Y.; Rao, A. M.; Grigorian, L.; Richter, E.; Eklund, P. C.; Phys. Rev. Lett. 1998, 80, 3779.

47. Rols, S.; Righi, A.; Alvarez, L.; Eur. Phys. J. B 2000, 18, 201.

48. Heracleous, E.; Lemonidou, A. A.; J. Catal. 2006, 237, 162.

49. Zhao, Z. K.; Yung, M. M.; Ozkan, U. S.; Catal. Commun. 2008, 9, 1465.

50. Brukh, R.; Mitra, S.; J. Mater. Chem. 2007, 17, 619.

51. Rao, C. N. R.; Satishkumar, B. C.; Govindaraj, A.; Nath, M.; ChemPhysChem 2001, 2, 78.

52. Kong, J.; Soh, H. T.; Cassell, A. M.; Quate, C. F.; Dai, H.; Nature 1998, 395, 878.

53. Saib, A. M.; Claeys, M.; van Steen, E.; Catal. Today 2002, 71, 395.

54. Reshetenko, T. V.; Avdeeva, L. B.; Ushakov, V. A.; Appl. Catal. A: Gen. 2004, 270, 87.

Submitted: November 27, 2011

Published online: April 10, 2012 